\title{
Role of intrafamilial transmission in high prevalence of hepatitis C virus in Egypt
}

This article was published in the following Dove Press journal:

Hepatic Medicine: Evidence and Research

14 June 2017

Number of times this article has been viewed

\author{
Maha Z Omar' \\ Mohamed A Metwally' \\ Hala M El-Feky' \\ Inas A Ahmed ${ }^{2,3}$ \\ Mohamed A Ismail ${ }^{4}$ \\ Amal Idris 2,3 \\ 'Department of Hepatology, \\ Gastroenterology, and Infectious \\ Diseases, ${ }^{2}$ Department of Medical \\ Biochemistry, ${ }^{3}$ Molecular Biology and \\ Biotechnology Unit, Benha University, \\ Benha, ${ }^{4}$ Department of Hepatology \\ and Gastroenterology, Dekernes \\ General Hospital, Dekernes, Egypt
}

Correspondence: Mohamed A Metwally Department of Hepatology, Gastroenterology, and Infectious Diseases, Benha University Hospital, PO Box 315।8, Benha, Qualubia, Egypt

Tel +201064917959

Fax $+2013322863 \mid$

Email mohamed.metwally@fmed.bu.edu.eg
Background: Egypt has the highest prevalence of hepatitis $\mathrm{C}$ virus (HCV) worldwide. Although an effective HCV treatment program has been adopted, it is estimated that the number of newly reported cases in Egypt is still high. Intrafamilial transmission may play a role in the high prevalence of $\mathrm{HCV}$ in Egypt. Identification of risk factors for the transmission of HCV may help in decreasing its prevalence and eliminating its infection.

Aim: The aim of this study was to estimate the prevalence of HCV infection among the household contacts of HCV patients and identify the possible risk factors associated with intrafamilial transmission.

Methods: This study was designed as a cohort study of 90 families of patients with confirmed chronic HCV and 38 families of non-HCV-infected persons. Diagnosis of HCV infection was performed by detection of HCV antibodies by fourth-generation enzyme-linked immunosorbent assay and confirmed by HCV RNA polymerase chain reaction. A pre-prepared questionnaire on risk factors was filled out by the participants. The prevalence of HCV was calculated, and univariate and multivariate analyses were carried out to identify the independent risk factors.

Results: Among 90 positive-index families, 32 (35.6\%) had contact persons with HCV infection compared to two of $38(5.3 \%)$ negative-index families $(P<0.001$, odds ratio $[\mathrm{OR}]=9.9)$. Out of 257 index-positive contacts, $38(14.8 \%)$ were infected compared to three of $75(4 \%)$ of index-negative contacts $(P=0.01, \mathrm{OR}=4.3)$. Infection was associated with older age $(6.9 \%$ of those aged $<20$ years, $10.4 \%$ of those aged $20-39$ years, and $22 \%$ of those aged $\geq 40$ years were infected) $(P=0.007)$. Husbands of infected wives were at a higher risk (33\% infected) than wives $(13.5 \%)$ and sons $(16.9 \%)(P<0.001)$. A history of hepatic encephalopathy was the independent predictor of intrafamilial transmission $(P<0.001, \mathrm{OR}=5.4)$.

Conclusion: Intrafamilial transmission was found to possibly play a major role in the high prevalence of HCV in Egypt. Transmission was associated with older age and contact with patients with hepatic encephalopathy and was high among husbands of infected wives.

Keywords: intrafamilial, transmission, HCV, prevalence, Egypt

\section{Introduction}

Hepatitis $\mathrm{C}$ virus (HCV) infects over 170 million humans worldwide, of whom $70 \%-80 \%$ become long-term carriers. Only a minority of infected individuals clear the virus spontaneously, whereas $30-60 \%$ of them develop chronic liver disease and a substantial percentage develops cirrhosis or even hepatocellular carcinoma. ${ }^{1,2}$ Egypt has the highest prevalence of hepatitis $\mathrm{C}$ in the world. ${ }^{3}$ The 2008 Egyptian 
Demographic Health Survey measured the HCV prevalence as $14.7 \%$ among a nationally representative sample of 11,126 Egyptians aged $15-59$ years. $^{4}$

Transmission of HCV infection usually occurs through parenteral route, including needle sharing and occupational injuries caused by contaminated needles, tattooing, and hemodialysis or contaminated medical equipments. However, at least $50 \%$ of all HCV-positive patients do not have a clear history of parenteral or other risk factors. ${ }^{5}$ In areas with a high prevalence, intrafamilial transmission is suggested to play an important role. In its common use, intrafamilial transmission refers to transmission occurring between patients infected with HCV and their household members including their immediate relatives, sexual partners, and other individuals sharing the same house despite the absence of a common genetic background. Because of shared behaviors and living conditions, family members within a household are likely to be more similar to one another than relatives from different households. The two patterns of intrafamilial transmission of HCV are horizontal transmission and perinatal transmission. Perinatal transmission was studied and was found to have a minimal role in the transmission even in Egypt with no difference from figures all over the world. ${ }^{6,7}$

Horizontal transmission is the spread of HCV from one person to another who are not in a mother-child relationship in the pre- and/or perinatal period. ${ }^{8}$ The study of horizontal intrafamilial transmission is complicated. The routes of horizontal intrafamilial transmission of HCV are multiple and often vary among different geographical areas, and such a transmission can occur simultaneously in the same family. ${ }^{9,10}$ For a large proportion of $\mathrm{HCV}$-infected patients who had not been exposed to any obvious risk factor, intrafamilial transmission was suspected; however, the occurrence of such transmission has been debated. ${ }^{11}$

\section{Aim}

The aim of this study was to estimate the prevalence of HCV infection among household contacts of known HCV patients in comparison with noninfected persons and identify the possible risk factors for the transmission of $\mathrm{HCV}$.

\section{Patients and methods}

This study was designed as a cohort study of household contacts of $90 \mathrm{HCV}$-positive patients (exposed group) in comparison with household contacts of 38 non-HCV-infected persons (nonexposed group). The study protocol was approved by the ethical committee of Benha Faculty of Medicine. All patients and volunteer subjects gave written informed consent before the study. Index-positive patients were defined as patients with positive $\mathrm{HCV}$ antibodies (Abs) detected by fourthgeneration enzyme-linked immunosorbent assay (ELISA) and confirmed by HCV RNA polymerase chain reaction (PCR). These patients were recruited from the Department of Hepatology, Gastroenterology, and Infectious Diseases, Benha University Hospital (outpatient and inpatient clinic). Index-negative subjects were defined as non-HCV-infected volunteer individuals diagnosed as negative for HCV Abs by ELISA, who were recruited from the same geographical area as index-positive patients. Benha University Hospital receives patients from almost all rural and some urban areas of Qalyubia, Monufia, Gharbia, and Sharqia governorates, which are part of the Nile Delta area. Household contacts were defined as persons who were living with the index subject in the same house for at least 1 year. A pre-prepared questionnaire on demographic data and risk factors was filled by a single interviewer. Socioeconomic status was classified according to a well-validated simple scoring system for social classification in Egypt. ${ }^{12}$ Detailed clinical history, including suggested risk factors for possible intrafamilial transmission, was evaluated, and clinical examination, laboratory investigation, and abdominal ultrasound were performed for all HCV-positive index and data were collected.

\section{Laboratory methods}

At the time of family interview, $3 \mathrm{~mL}$ of peripheral blood was withdrawn from each subject into a sterile vacutainer and allowed to clot. After centrifugation, the obtained sera were aliquoted and kept frozen at $-20^{\circ} \mathrm{C}$ till further processing.

Serum samples were used for detection of serum HCV Abs (IgG) in duplicates, using Murex anti-HCV (version 4.0) ELISA kit (Murex Biotech, Dartford, UK), on a microplate reader (Tecan, Männedorf, Switzerland). ${ }^{13}$ The reactive samples were then used for quantification of HCV load in serum.

The QIAamp Viral RNA Mini Kits were used for viral RNA extraction by Qiacube automatic extractor (Qiagen, Hilden, Germany). Quantitative real-time (RT) PCR assays were performed by absolute quantitation method using artus HCV RG RT-PCR Kit (Qiagen). Four quantitation standards were used to generate standard curves on Step One RT-PCR system (Applied Biosystems, Foster City, CA, USA). The results were calculated using the following equation:

$$
\begin{gathered}
\text { result }(\mathrm{IU} / \mathrm{mL})=\operatorname{result}(\mathrm{IU} / \mu \mathrm{L}) \times \text { elution volume }(\mu \mathrm{L}) \\
/ \text { sample volume }(\mathrm{mL}) .
\end{gathered}
$$

The manufacturers' instructions were followed throughout all the steps.

The prevalence of $\mathrm{HCV}$ among household contacts of positive and negative index was calculated with $95 \%$ 
confidence interval (CI), and comparison between them was made by using Chi-square test. Comparison between families of positive index and families of negative index was made with calculation of odds ratio (OR). Univariate and multivariate analyses were carried out for comparing infected contacts with noninfected contacts to identify risk factors.

\section{Results}

We included 90 families with HCV-positive index with their contacts (257 persons), and 38 families with HCV-negative index with their contacts (75 persons). Table 1 shows the descriptive data of the index-positive patients, index-negative patients, and their contacts. The majority of studied subjects were males, and the mean age was higher among the HCVpositive-index cases $(52.1 \pm 9.6$ years $)$ than other groups.
Most of our population was from rural areas with a middle socioeconomic standard of living.

Comparison between HCV-positive and HCV-negative patients by univariate and logistic regression analyses to identify the risk factors for acquisition of $\mathrm{HCV}$ in our population is shown in Tables 2 and 3. The independent predictors of risk factors for $\mathrm{HCV}$ infection in general were male gender $(P$ $<0.001)$, advanced age $(P<0.001)$, and exposure to blood transfusion $(P=0.03)$ (Table 3$)$.

Regarding intrafamilial transmission, out of 90 families with HCV-positive index, 32 of them (35.6\%) had one or more HCV-positive contact in comparison to two out of 38 families $(5.3 \%)$ with $\mathrm{HCV}$-negative index $(P<0.001, \mathrm{OR}=$ 9.93, 95\% CI = 2.24-43.97). This means that families with one positive member have almost a tenfold increased risk

Table I Description of the studied population

\begin{tabular}{|c|c|c|c|}
\hline Parameter & $\begin{array}{l}\text { HCV index positive } \\
(N=90), n(\%) \text { or } \\
\text { mean }( \pm S D)\end{array}$ & $\begin{array}{l}\text { HCV index negative } \\
(\mathbf{N}=38), n(\%) \text { or } \\
\text { mean }( \pm S D)\end{array}$ & $\begin{array}{l}\text { Contact } \\
(\mathrm{N}=332), \mathrm{n}(\%) \text { or } \\
\text { mean }( \pm \mathrm{SD})\end{array}$ \\
\hline Gender, male & $62(68.9)$ & $24(63.2)$ & $|4|(42.5)$ \\
\hline Age (years) & $52.1( \pm 9.6)$ & $38.9( \pm 8.9)$ & $29.9( \pm 14.9)$ \\
\hline \multicolumn{4}{|l|}{ Occupation } \\
\hline Not working & $29(32.2)$ & $9(23.7)$ & $233(70.2)$ \\
\hline Farmer & $20(22.2)$ & $2(5.5)$ & $16(4.8)$ \\
\hline Worker & $12(13.3)$ & $3(7.5)$ & $21(6.3)$ \\
\hline Technician & $12(13.3)$ & $4(10.5)$ & $26(7.8)$ \\
\hline Professional & $14(15.6)$ & $7(18.4)$ & $23(6.9)$ \\
\hline Health care worker & $3(3.3)$ & $13(34.2)$ & $13(3.9)$ \\
\hline \multicolumn{4}{|l|}{ Residence } \\
\hline Rural & $83(92.2)$ & $37(97.4)$ & $313(94.3)$ \\
\hline Urban & $7(7.8)$ & I (7.9) & $19(5.7)$ \\
\hline \multicolumn{4}{|l|}{ Education } \\
\hline Illiterate & $32(35.6)$ & $7(18.4)$ & $64(19.3)$ \\
\hline Less than secondary & $22(24.4)$ & $3(7.9)$ & $104(31.3)$ \\
\hline Secondary & $18(20)$ & II (28.9) & $103(31)$ \\
\hline University & $18(20)$ & $17(44.7)$ & $61(18.4)$ \\
\hline \multicolumn{4}{|l|}{ Socioeconomic status } \\
\hline Low & $15(16.7)$ & $3(7.9)$ & $38(10.4)$ \\
\hline Middle & $68(75.6)$ & $32(84.2)$ & $269(81)$ \\
\hline High & $7(7.7)$ & $3(7.9)$ & $25(7.6)$ \\
\hline \multicolumn{4}{|l|}{ Marital status } \\
\hline Not married & $3(3.3)$ & $3(7.9)$ & $137(4 \mid .3)$ \\
\hline Married & $76(84.4)$ & $32(84.2)$ & $185(55.7)$ \\
\hline Divorced & 0 & $0(0)$ & I $(0.3)$ \\
\hline Widow & II (I2.2) & $3(7.9)$ & $9(2.7)$ \\
\hline \multicolumn{4}{|l|}{ Anti-bilharzial treatment } \\
\hline No & II (I2.2) & $4(10.5)$ & $154(46.4)$ \\
\hline Oral & $72(80)$ & $34(89.5)$ & $173(52.1)$ \\
\hline Parenteral & $3(3.3)$ & $0(0)$ & $4(1.2)$ \\
\hline Both & $4(4.5)$ & $0(0)$ & $\mathrm{I}(0.3)$ \\
\hline Previous operation & $66(73.3)$ & $22(57.9)$ & $165(49.7)$ \\
\hline Blood transfusion & $39(43.3)$ & $7(18.4)$ & $45(13.6)$ \\
\hline Injection, medication & 77 (85.6) & $35(92.1)$ & $213(64.2)$ \\
\hline Dental procedure & $44(49.5)$ & $30(78.9)$ & $167(50.3)$ \\
\hline Dialysis & $7(7.8)$ & $0(0)$ & $2(0.6)$ \\
\hline
\end{tabular}

Abbreviations: $\mathrm{HCV}$, hepatitis $\mathrm{C}$ virus; $\mathrm{SD}$, standard deviation. 
Table 2 Comparison between HCV-positive and HCV-negative studied population

\begin{tabular}{|c|c|c|c|}
\hline Parameters & $\begin{array}{l}\text { HCV positive } \\
(\mathbf{N}=13 \mathrm{I}) \\
\mathbf{n}(\%) \text { or } \\
\text { mean }( \pm \mathrm{SD})\end{array}$ & $\begin{array}{l}\text { HCV negative } \\
(N=329), \\
n(\%) \text { or mean } \\
( \pm S D)\end{array}$ & $P$-value \\
\hline Gender, male & $83(63.4)$ & $144(43.8)$ & $<0.001$ \\
\hline Age (years) & $47.2( \pm \mid 3.8)$ & $30.1( \pm I 4.4)$ & $<0.001$ \\
\hline \multicolumn{4}{|l|}{ Occupation } \\
\hline Not working & $53(40.5)$ & $218(66.3)$ & $<0.001$ \\
\hline Farmer & $23(17.6)$ & $15(4.6)$ & \\
\hline Worker & $17(13)$ & $19(5.8)$ & \\
\hline Technician & $14(10.7)$ & $28(8.5)$ & \\
\hline Professional & $20(15.3)$ & $24(7.3)$ & \\
\hline Health care & $4(3.1)$ & $25(7.6)$ & \\
\hline \multicolumn{4}{|l|}{ worker } \\
\hline \multicolumn{4}{|l|}{ Residence } \\
\hline Rural & $122(93.1)$ & $311(94.5)$ & 0.6 \\
\hline \multicolumn{4}{|l|}{ Education } \\
\hline Illiterate & $42(32.1)$ & $61(18.5)$ & 0.016 \\
\hline Less than & $35(26.7)$ & $94(28.6)$ & \\
\hline \multicolumn{4}{|l|}{ secondary } \\
\hline Secondary & 31 (23.7) & 101 (30.7) & \\
\hline University & $23(17.6)$ & $73(22.2)$ & \\
\hline \multicolumn{4}{|l|}{ Socioeconomic } \\
\hline \multicolumn{4}{|l|}{ status } \\
\hline Low & $20(15.3)$ & $36(10.9)$ & 0.4 \\
\hline Middle & $102(77.9)$ & $267(8 \mid .2)$ & \\
\hline High & $9(6.8)$ & $26(7.9)$ & \\
\hline \multicolumn{4}{|l|}{ Marital status } \\
\hline Not married & 14 (10.7) & $129(39.2)$ & $<0.001$ \\
\hline Married & $103(78.6)$ & 191 (58.1) & \\
\hline Divorced & $0(0)$ & $\mathrm{I}(0.3)$ & \\
\hline Widow & $14(10.7)$ & $8(2.4)$ & \\
\hline $\begin{array}{c}\text { Duration of } \\
\text { marriage (years) }\end{array}$ & $22.5( \pm 13.1)$ & $9.5( \pm 1 \mid .5)$ & $<0.001$ \\
\hline \multicolumn{4}{|c|}{ Anti-bilharzial treatment } \\
\hline No & $20(15.3)$ & 149 (45.3) & $<0.001$ \\
\hline Oral & $103(78.6)$ & $176(53.5)$ & \\
\hline Parenteral & $4(3.1)$ & $3(0.9)$ & \\
\hline Both & $4(3.1)$ & $\mathrm{I}(0.3)$ & \\
\hline $\begin{array}{l}\text { Previous } \\
\text { operation }\end{array}$ & $90(68.7)$ & $163(49.5)$ & $<0.001$ \\
\hline $\begin{array}{l}\text { Blood } \\
\text { transfusion }\end{array}$ & 44 (33.6) & $47(14.3)$ & $<0.001$ \\
\hline $\begin{array}{l}\text { Injection, } \\
\text { medication }\end{array}$ & $108(82.4)$ & $217(66)$ & $<0.001$ \\
\hline $\begin{array}{l}\text { Dental } \\
\text { procedure }\end{array}$ & $66(50.8)$ & 175 (53.2) & 0.7 \\
\hline Dialysis & $8(6.1)$ & $\mathrm{I}(0.3)$ & $<0.001$ \\
\hline
\end{tabular}

Abbreviations: $\mathrm{HCV}$, hepatitis $\mathrm{C}$ virus; $\mathrm{SD}$, standard deviation.

Table 3 Forward logistic regression analysis of predictors of $\mathrm{HCV}$ infection

\begin{tabular}{llll}
\hline Predictors & OR & $\mathbf{9 5 \%} \mathbf{C l}$ & P-value \\
\hline Gender, female & 0.29 & $0.174-0.488$ & $<0.001$ \\
Age & 1.085 & $1.065-1.106$ & $<0.001$ \\
Blood transfusion & 1.914 & $1.066-3.436$ & 0.03 \\
\hline
\end{tabular}

Abbreviations: $\mathrm{HCV}$, hepatitis $\mathrm{C}$ virus; $\mathrm{OR}$, odds ratio; $\mathrm{Cl}$, confidence interval. of having another positive member within the family. Out of 257 index-positive contacts, 38 (14.8\%) were infected in comparison with three of $75(4 \%)$ index-negative contacts $(P$ $=0.01, \mathrm{OR}=4.3,95 \% \mathrm{CI}=1.3-14.5)$. This means that each family member in contact with the HCV-positive patient has almost a fourfold increased risk of getting infected.

There was a highly statistically significant difference in the prevalence of HCV among different age groups; prevalence was high (22\%) in the advanced age group $(\geq 40$ years) (Table 4). Regarding the relation between HCV status and kinship to index cases, we demonstrated that husbands of HCV-positive females were at a higher risk followed by sons (33.3\% and $16.9 \%$, respectively) and wives of HCVpositive males and daughters ( $13.5 \%$ and $5.1 \%$, respectively) (Table 5). Regarding the duration of marriage, we found that HCV-positive cases had insignificantly longer duration of marriage than negative cases $(P=0.5)$.

Risk of intrafamilial transmission of $\mathrm{HCV}$ infection was higher in the decompensated liver cirrhosis group (30\%) than control group (5.3\%) with a highly statistically significant difference between both the groups $(P=0.004, \mathrm{OR}=7.71)$. However, there was an insignificant difference between compensated and decompensated liver cirrhosis groups due to $\mathrm{HCV}$ infection regarding risk of intrafamilial transmission $(P=0.2)$. There was a highly statistically significant difference between numbers of contact with HCV infection in families ( 94 families did not have any HCV-positive contacts, 27 families had only one HCV-positive contact, and seven

Table 4 Distribution of HCV status among household contacts according to age group

\begin{tabular}{lllll}
\hline $\begin{array}{l}\text { Age group } \\
\text { (years) }\end{array}$ & $\begin{array}{l}\text { HCV positive, } \\
\mathbf{n}(\%)\end{array}$ & $\begin{array}{l}\text { HCV negative, } \\
\mathbf{n}(\%)\end{array}$ & Total & $\boldsymbol{P}$-value \\
\hline$<20$ & $6(6.9)$ & $81(93.1)$ & 83 & 0.007 \\
$20-39$ & $17(10.4)$ & $146(89.6)$ & 163 & \\
$\geq 40$ & $18(22)$ & $64(78)$ & 82 & \\
\hline
\end{tabular}

Abbreviation: $\mathrm{HCV}$, hepatitis $\mathrm{C}$ virus.

Table 5 Distribution of HCV status among contacts of indexpositive cases according to degree of kinship to index

\begin{tabular}{|c|c|c|c|c|}
\hline $\begin{array}{l}\text { Degree of } \\
\text { kinship }\end{array}$ & $\begin{array}{l}\text { HCV positive } \\
(N=38,14.8 \%), \\
n(\%)\end{array}$ & $\begin{array}{l}\text { HCV negative } \\
(\mathbf{N}=219, \\
85.2 \%), \mathrm{n}(\%)\end{array}$ & $\begin{array}{l}\text { Total } \\
(N=257)\end{array}$ & $P$-value \\
\hline Husband & $3(33.3)$ & $6(66.7)$ & 9 & $<0.000$ \\
\hline Wife & $7(13.5)$ & 45 (86.5) & 52 & \\
\hline Son & $13(16.9)$ & $64(83.1)$ & 77 & \\
\hline Daughter & $3(5.1)$ & 56 (94.9) & 59 & \\
\hline Sister & $3(20)$ & $12(80)$ & 15 & \\
\hline Brother & I (I2.5) & 7 (87.5) & 8 & \\
\hline Others & $8(17.1)$ & $39(82)$ & 47 & \\
\hline
\end{tabular}

Abbreviation: $\mathrm{HCV}$, hepatitis $\mathrm{C}$ virus. 
families had two $\mathrm{HCV}$-positive contacts) regarding presence of positive index cases, compensated liver cirrhosis, history of encephalopathy, history and presence of ascites, palmar erythema, and flabbing tremors (Table 6). By performing a logistic regression analysis of previous significant parameters, we found that only history of encephalopathy was the most prominent risk factor for intrafamilial transmission of $\mathrm{HCV}$ infection $(P<0.001, \mathrm{OR}=5.422,95 \% \mathrm{CI}=$ 2.099-14.006).

\section{Discussion}

Chronic hepatitis $\mathrm{C}(\mathrm{CHC})$ is a major health concern worldwide, and although often clinically silent, it is histologically an insidiously progressive disease leading to liver fibrosis, cirrhosis, and hepatocellular carcinoma. ${ }^{14}$ Egypt has been reported to have the highest prevalence of $\mathrm{HCV}$ worldwide, ranging from $6 \%$ to more than $40 \%$ in different regions and among different demographic groups. ${ }^{15}$ The route of transmission of HCV is still controversial and complicated. Transmission of blood or blood products leads to infection in the majority of cases. ${ }^{16}$ The household contacts of HCVseropositive patients had been shown to have an elevated risk of $\mathrm{HCV}$ infection. ${ }^{11,17}$ The present study revealed that the majority of studied patients were males, and this finding is in agreement with Mohamoud et al. ${ }^{4}$ This result may be in part attributed to the parenteral antischistosomiasis therapy,

Table 6 Comparison between families with no HCV-positive, single HCV-positive, and two HCV-positive contacts

\begin{tabular}{|c|c|c|c|c|}
\hline & \multicolumn{3}{|c|}{$\begin{array}{l}\text { Number of families (number } \\
\text { of contacts), } n(\%)\end{array}$} & \multirow[t]{2}{*}{$P$-value } \\
\hline & $94(0)$ & $27(I)$ & $7(2)$ & \\
\hline Index positive & $58(61.7)$ & $26(96.3)$ & $6(85.7)$ & 0.002 \\
\hline $\begin{array}{l}\text { Decompensated } \\
\text { cirrhosis }\end{array}$ & $23(24.5)$ & $13(48.1)$ & $4(57.1)$ & 0.004 \\
\hline \multicolumn{5}{|l|}{ Previous history } \\
\hline Encephalopathy & $10(10.6)$ & $13(48.1)$ & $3(42.9)$ & 0.001 \\
\hline Gastrointestinal & $12(12.7)$ & $6(22.2)$ & $2(28.6)$ & 0.6 \\
\hline \multicolumn{5}{|l|}{ bleeding } \\
\hline Ascites & $16(17.1)$ & 14 (5।.9) & $4(57.1)$ & 0.006 \\
\hline Pallor & $38(40.4)$ & $16(59.3)$ & 5 (7I.4) & 0.6 \\
\hline Jaundice & $21(22.3)$ & II (40.7) & $4(57.1)$ & 0.2 \\
\hline Cyanosis & $7(7.4)$ & $7(25)$ & I (I4.3) & 0.1 \\
\hline Palmar erythema & $24(25.5)$ & $16(59.3)$ & $5(71.4)$ & 0.02 \\
\hline Flabbing tremors & $12(12.7)$ & II (40.7) & $3(42.9)$ & 0.03 \\
\hline Palpable spleen & $24(25.5)$ & $14(51.9)$ & $3(42.9)$ & 0.3 \\
\hline Palpable liver & $13(13.8)$ & $3(I I . I)$ & $2(28.6)$ & 0.5 \\
\hline Ascites & & & & 0.003 \\
\hline Mild & $6(8.5)$ & $3(I I . I)$ & $2(28.6)$ & \\
\hline Moderate & $2(2.8)$ & $6(22.2)$ & $2(28.6)$ & \\
\hline Severe & $6(8.5)$ & $5(18.5)$ & I (I4.3) & \\
\hline
\end{tabular}

Abbreviation: $\mathrm{HCV}$, hepatitis $\mathrm{C}$ virus. as males were more affected by the schistosomiasis disease burden and hence were the main targets of these campaigns. We also found in this study that the mean age of HCV-positive cases was higher than HCV-negative cases (52.1 \pm 9.6 and $38.9 \pm 9.8$ years, respectively). This observation was previously reported in two studies from Egypt, where adults had a higher HCV prevalence (15.7\%) than children (4\%). ${ }^{15,18} \mathrm{We}$ also found that the majority of $\mathrm{HCV}$-positive cases were from rural areas (92.2\%). These data confirm that Egypt has the highest prevalence of $\mathrm{HCV}$ infection averaging 15\%-25\% in rural communities as previously reported by two other studies. ${ }^{19,20}$ In the current study, we demonstrated that male gender, advanced age, and exposure to blood transfusion in the whole studied population were risk factors for acquiring $\mathrm{HCV}$ infection. Minola et al reported similar results as they studied risk factors for intrafamilial transmission of $\mathrm{HCV}$ infection and found that age $(\mathrm{OR}=1.01, P=0.07)$, gender (females versus males: $\mathrm{OR}=2.03, P<0.001$ ), intravenous (IV) drug use $(\mathrm{OR}=2.98, P<0.001)$, and blood transfusion $(\mathrm{OR}=0.6, P=0.03)$ were the major risk factors. ${ }^{11}$

Role of intrafamilial transmission in the high prevalence of HCV in Egypt was confirmed in our study. We found that $35.6 \%$ of families with HCV-positive index had a HCVpositive contact in comparison with only $5.2 \%$ of families with HCV-negative index. We also found that persons in contact with HCV-positive patients had a prevalence of $14.8 \%$ of $\mathrm{HCV}$ in comparison with $4 \%$ of those in contact with $\mathrm{HCV}$-negative persons. Role of intrafamilial transmission was also previously reported by other authors from Egypt and other countries. ${ }^{21,22}$

In the present work, the prevalence of $\mathrm{HCV}$ among husbands of infected females was 33.3\% (3/9) and prevalence among wives of infected husbands was $13.5 \%$ (5/52), which suggests a higher transmission from infected wives to their husbands. However, this transmission had no significant association with the duration of marriage. Similar results were reported by El-Bendary et al, ${ }^{16}$ who concluded that prevalence of positive anti-HCV Abs among wives was $17.8 \%$ $(10 / 56)$, while the prevalence of positive anti-HCV Abs among husbands was $36.4 \%(8 / 22)$. However, they found that anti-HCV-positive spouses had longer duration of marriage than negative spouses, which was not confirmed in our study. Many studies reported that the longer the duration of marriage, the higher the risk of $\mathrm{HCV}$ infection. The risk of $\mathrm{HCV}$ infection for the spouse was found to be increased after 15 years. ${ }^{23,24}$ Marriage did not only include a sexual relationship but also other kinds of body contact and exposure to the same risk factors (ie, sharing the same personal tools, exposure to blood of the index case by any means). ${ }^{25}$ In the current study, 
HCV prevalence rates were high among offspring (16.9\% for sons and $5.1 \%$ for daughters) of HCV-positive cases. This result was in concordance with that reported by El-Bendary et al, ${ }^{16}$ who found that the prevalence was $6.8 \%$ for sons and $4.94 \%$ for daughters. Several Japanese studies have revealed high prevalence rates among offspring of chronic HCV patients, for example, the study by Nishiguchi et al $(20.9 \%)$ and Hayashi et al (16.9\%). ${ }^{26,27}$ On the other hand, Napoli et al and Kim et al reported low prevalence rates among offspring (2.3\% and $0 \%$, respectively). ${ }^{28,29}$

In the current study, we found that HCV positivity was significantly high among subjects aged $\geq 40$ years $(22 \%)$, and this agreed with the study by Arafa et al, ${ }^{30}$ who reported that the prevalence of HCV Abs in rural area of Egypt increased from $2.7 \%$ in those $<20$ years of age to more than $40 \%$ in males whose age ranged from 40 to 54 years. Similarly, Paez Jimenez et al reported that prevalence of chronic HCV infection in Egypt increased with age reaching $>25 \%$ among persons aged $>50$ years. ${ }^{10}$

We also found that those in contact with patients with decompensated liver cirrhosis have a higher risk of being infected with HCV $(\mathrm{OR}=7.71)$, especially if the patient has hepatic encephalopathy which is an independent predictor of infection. These findings could be explained by increased risky behaviors of those in contact with the cases without taking precautions, such as giving IV injections and doing enemas.

\section{Limitations}

This study has some limitations. There is no temporal factor because it is not a prospective cohort study, and hence, there is a limitation of causality relationship. The second limitation is the absence of phylogenetic study which confirms the same genotype and subtype in the family. Another limitation is that we cannot rule out getting the infection for index and contacts from the same source outside the family.

\section{Conclusion}

Intrafamilial transmission of HCV possibly plays an important role in the high prevalence of HCV in Egypt, which supports screening of family members of HCV patients. Contact with a family member with decompensated cirrhosis especially hepatic encephalopathy increases the risk of intrafamilial transmission which necessitates an educational program for families with a chronic liver disease patient.

\section{Acknowledgment}

The authors would like to thank Scientific Research Fund, Benha University, Egypt, for funding this research project.

\section{Author contributions}

All authors contributed toward data analysis, drafting and critically revising the paper and agree to be accountable for all aspects of the work.

\section{Disclosure}

The authors report no conflicts of interest in this work.

\section{References}

1. Ghany MG, Strader DB, Thomas DL, Seeff LB; American Association for the Study of Liver Diseases. Diagnosis, management and treatment of hepatitis C: an update. Hepatology. 2009;49(4):1335-1374.

2. Fani A, Fani I, Eshratie B, Samadian P, Fani P, Gorishi Y. Screening for hepatocellular carcinoma in hepatitis B and C chronic carriers in Iran. Indian J Gastroenterol. 2007;26(6):297-298.

3. Mohamed MK. Epidemiology of HCV in Egypt. Afro-Arab Liver J. 2004;3(2):41-52.

4. Mohamoud YA, Mumtaz GR, Riome S, Miller D, Abu-Raddad LJ. The epidemiology of hepatitis $C$ virus in Egypt: a systematic review and data synthesis. BMC Infect Dis. 2013;13:288.

5. La Torre G, Miele L, Mannocci A, et al; HCV-Southern Lazio Collaborative Group. Correlates of HCV seropositivity among familial contacts of HCV positive patients. BMC Public Health. 2006;6:237.

6. Stoszek SK, Abdel-Hamid M, Narooz S, et al. Prevalence of and risk factors for hepatitis $\mathrm{C}$ in rural pregnant Egyptian women. Trans $R$ Soc Trop Med Hyg. 2006;100(2):102-107.

7. AbdulQawi K, Youssef A, Metwally MA, Ragih I, AbdulHamid M, Shaheen A. Prospective study of prevalence and risk factors for hepatitis $\mathrm{C}$ in pregnant Egyptian women and its transmission to their infants. Croat Med J. 2010;51(3):219-228.

8. Indolfi G, Nesi A, Resti M. Intrafamilial transmission of hepatitis C virus. J Med Virol. 2013;85(4):608-614.

9. Plancoulaine S, Mohamed MK, Arafa N, et al. Dissection of familial correlations in hepatitis $\mathrm{C}$ virus (HCV) seroprevalence suggests intrafamilial viral transmission and genetic predisposition to infection. Gut. 2008;57(9):1268-1274.

10. Paez Jimenez A, Mohamed MK, Eldin NS, et al. Injection drug use is a risk factor for HCV infection in urban Egypt. PLoS One. 2009; 4(9):e7193.

11. Minola E, Baldo V, Baldovin T, Trivello R, Floreani A. Intrafamilial transmission of hepatitis C virus infection. Eur J Epidemiol. 2006; 21(4):293-297.

12. Fahmy SI, El-Sherbiny AF. Determining simple parameters for social classification for health research. Bull High Inst Public Health. 1983;13(5):95-108.

13. Botté $\mathrm{C}$, Janot C. Epidemiology of HCV infection in the general population and in blood transfusion. Nephrol Dial Transplant. 1996;11 (Suppl4): $19-21$.

14. Attallah AM, Shiha GE, Omran MM, Zalata KR. A discriminant score based on four routine laboratory blood tests for accurate diagnosis of severe fibrosis and/or liver cirrhosis in Egyptian patients with chronic hepatitis C. Hepatol Res. 2006;34(3):163-169.

15. Lehman EM, Wilson ML. Epidemic hepatitis C virus infection in Egypt: estimates of past incidence and future morbidity and mortality. JViral Hepat. 2009;16(9):650-658.

16. El-Bendary M, Esmat G, Neamatallah M, et al. Epidemiological aspects of intrafamilial spread of HCV infection in Egyptian population: a pilot study. Open J Gastroenterol. 2014;4(5):228-236.

17. Tibbs CJ. Methods of transmission of hepatitis C. J Viral Hepat. 1995; 2(3):113-119.

18. Khattab MA, Eslam M, Sharwae MA, Hamdy L. Seroprevalence of hepatitis $\mathrm{C}$ and B among blood donors in Egypt: Minya Governorate, 2000-2008. Am J Infect Control. 2010;38(8):640-641. 
19. Miller FD, Abu-Raddad LJ. Evidence of intense ongoing endemic transmission of hepatitis C virus in Egypt. Proc Natl Acad Sci U SA. 2010; 107(33):14757-14762.

20. Ackerman Z, Ackerman E, Paltiel O. Intrafamilial transmission of hepatitis C virus: a systematic review. JViral Hepat. 2000;7(2):93-103.

21. El-Dien Nouh MA, AlFateh Mahrous OA, Zekry Farg IA. Intrafamilial transmission of hepatitis $\mathrm{C}$ virus in Menoufia Governorate. Menoufia Med J. 2014;27(2):478-483.

22. Lankarani KB, Ardebili M, Sepehrimanesh M, et al. Evaluation of hepatitis $\mathrm{C}$ virus intrafamilial transmission among families with one index case, a pilot study from Fars province, Iran. Gastroenterol Hepatol Bed Bench. 2016;9(4):250-258.

23. Meisel H, Reip A, Faltus B, et al. Transmission of hepatitis C virus to children and husbands by women infected with contaminated anti-D immunoglobulin. Lancet. 1995;345(8959):1209-1211.

24. Kao JH, Hwang YT, Chen PJ, et al. Transmission of hepatitis C virus between spouses: the important role of exposure duration. Am J Gastroenterol. 1996;91(10):2087-2090.
25. Cavalheiro Nde P, De La Rosa A, Elagin S, Tengan FM, Araújo ES, Barone AA. Hepatitis C: sexual or intrafamilial transmission? Epidemiological and phylogenetic analysis of hepatitis $C$ virus in 24 infected couples. Rev Soc Bras Med Trop. 2009;42(3):239-244.

26. Nishiguchi S, Kuroki T, Fukuda K, et al. Familial clustering of HCV. Lancet. 1992;339(8807):1486.

27. Hayashi J, Kishihara Y, Yamaji K, et al. Transmission of hepatitis C virus by health care workers in a rural area of Japan. Am J Gastroenterol. 1995; 90(5):794-799.

28. Napoli N, Fiore G, Vella F, Fera G, Schiraldi O. Prevalence of antibodies to hepatitis $\mathrm{C}$ virus among family members of patients with chronic hepatitis C. Eur J Epidemiol. 1993;9(6):629-632.

29. Kim YS, Ahn YO, Kim DW. Familial clustering of hepatitis B and C viruses in Korea. J Korean Med Sci. 1994;9(6):444-449.

30. Arafa N, El Hoseiny M, Rekacewicz C, et al. Changing pattern of hepatitis $\mathrm{C}$ virus spread in rural areas of Egypt. J Hepatol. 2005;43(3): 418-424.
Hepatic Medicine: Evidence and Research

\section{Publish your work in this journal}

Hepatic Medicine: Evidence and Research is an international, peerreviewed, open access journal covering all aspects of adult and pediatric hepatology in the clinic and laboratory including the following topics: Pathology, pathophysiology of hepatic disease; Investigation and treatment of hepatic disease; Pharmacology of drugs used for the treatment

\section{Dovepress}

of hepatic disease. Issues of patient safety and quality of care will also be considered. The manuscript management system is completely online and includes a very quick and fair peer-review system, which is all easy to use. Visit http://www.dovepress.com/testimonials.php to read real quotes from published authors.

Submit your manuscript here: https:/www.dovepress.com/hepatic-medicine-evidence-and-research-journal 